\title{
Architecture of the future in the eastern europe: reality and illusions
}

\begin{abstract}
This paper presents the outcomes of two international conferences: 'On the way to architectural education and the profession of the future' and 'Genesis and development directions of the future architecture in the Eastern Europe', which took place on 28 November 2018 and 28 November 2019, respectively, at the Lviv Polytechnic National University.

During the conference, educationalists, researchers, experts from architectural and artistic schools of Ukraine from Lviv, Kyiv, Odessa, Chernivtsi, Dnipro, Lutsk; Poland-from the city of Kielce; Germany-from Dresden University of Technology; Canada-from the city of Toronto, discussed what had to be done and done unquestionably so that we could not only dream about an architecture of the future but also actively create it.

Not asking a formal request of the speakers to present what came out of the predictions of the architects / futurists of the twentieth century directed, according to their understanding, into close (the 1970s and 80s), non-distant (the 1990s) and distant future (the turn of the twenty-first century). Instead, they wanted to plant into the architectural reality of modern Eastern Europe, and Ukraine, Poland, Germany in particular, those sprouts of the new in architecture which are associated with 'the architecture of the future' and that are currently being born and their blooming can be expected in the Eastern Europe and the world in the future.
\end{abstract}

Keywords: progressive, real, experimental futuristic architectural ideas, concepts, projects in Ukraine, Eastern Europe, world

The past cannot be changed only because of its nature. The present has to be accepted the way it is and we have to control it.

While the future is open... open to the artistic thought and activity.

Ludwig Mies van der Rohe.

\section{Introduction}

The X CIAM congress in Dubrovnik in 1956 is considered to be the beginning of the search for the architecture of the future when architects expressed the statements opposing the ideas of the Athens Charter for the first time. Why exactly at that time? Because for the first time the thoughts about the future coincided for both practising architects, who united to form TEAM $X$, and young architects, whose main vector was creating fantasy projects of buildings and entire cities of the future that were based on their own ideas of architecture's development.

This movement was definitively formed at the beginning of the 1960s, when at the UIA Congress in Paris, a group of young but already well-known architects, organised an exhibition of its twelve projects of the cities of the future; in parallel, other architect societies began operating - the architects of the Metabolism movement in Japan, Archigram in England etc. All these and other societies chose their leaders. For the Metabolists, it was K. Tange (ill. 1), for Archigram (ill. 2) it was P. Cook, while the organisers of Paris exhibition called M. Ragon their leader. It was M. Ragon's work, which he later arranged into the most famous publication among architects-Les cites de L'avenir - that is considered to have given the greatest impulse for architectural predictions of the future. This was not only because having studied the activity of hundreds of architects from the period between the end of the nineteenth century and the beginning of the twentieth centuryfrom Ledoux, Boullée to Goro, Eli, Paxton, Wagnet: the activity of 'architectural pioneers' such as Le Corbusier, Wright, Mies van der Rohe, Kiesler and others; his contemporaries Bakema, Rudolf, Aalto, van Eyck, Saarinen, Watson, Scharoun and others; those, who were considered to be the architects of the future at the time-Kahn, Johansson, Soleri, architects of the group of Candilis and Josic, Hoff, Castiglioni, Kikutake, Schulze-Fielitz, Fridman, or Hollein. Ragon tried to predict the events of the twentieth century. He also tried to predict the architecture in the twenty-first century (Ragon Michel, 1969, p. 296).

The very list of ideas of the abovementioned architects is astonishing even today-at the beginning of the twenty-first century. Even if everything what they declared, designed and built is generalised, their architectural work still makes us respect it due to its uniqueness and, in particular, the following:

- the proposal of the ideas of suspended, spatial cities and buildings;

* Viktor Proskuryakov Prof. D.Sc. PhD Eng. Arch., Department of Architectural Environment Design, Lviv Politechnic National University, ORCID: 0000-0003-1022-8984.e-mail: Viktor.I.Proskuriakov@Ipnu.ua

0002-9528-0038, e-mail: Yuliia.L.Bohdanova@lpnu.ua 


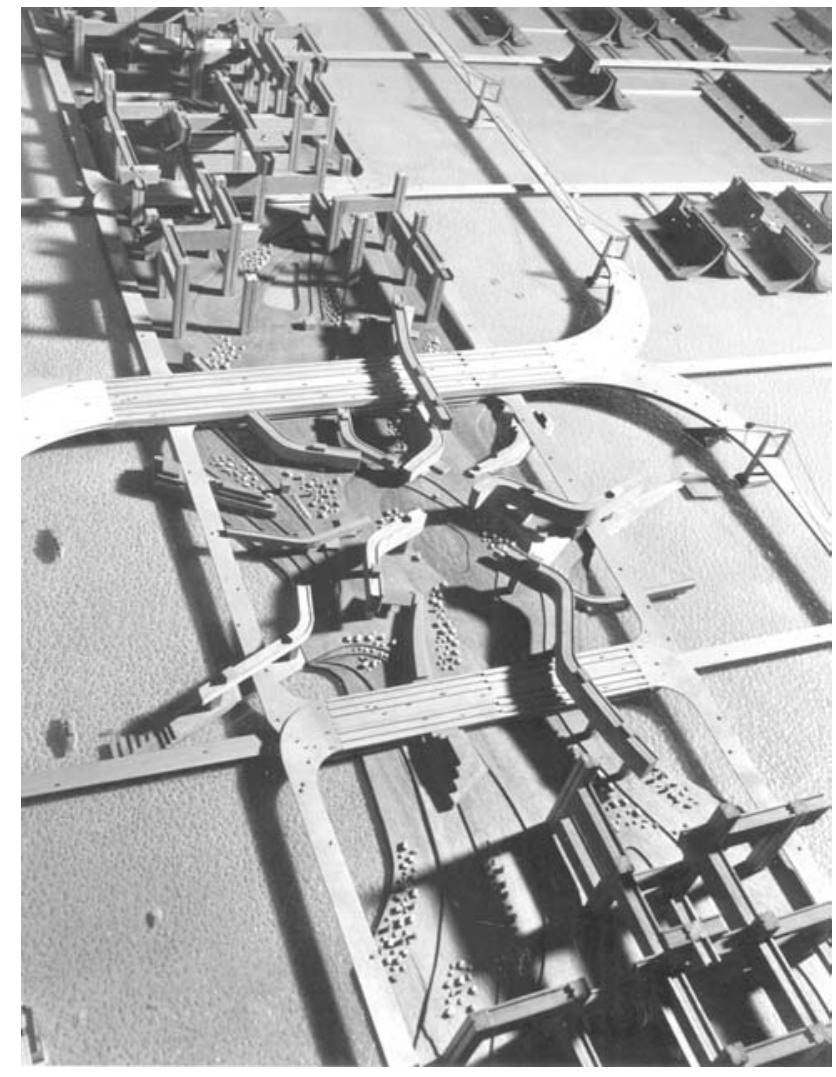

III.1. Plan for Tokyo 1960. Kenzō Tange (https://en.tangeweb.com/ works/works_no-22/ accessed: 10.02.2020)

- popularising the ideas of curvilinear, spiral and spherical shapes;

- ideas of architectural bionics, total architectural ecology;

- experiments in the directions of mobile, kinetic, transformative architecture;

- designing the interiors, furniture, equipment in places which can change their functions within a short period of time;

- developing the ideas of 'flexible architecture';
- creating the architecture / sculpture;

- using effective materials-aluminium, plastic, polymers;

- measures to eliminate the existing differences between the city and the village;

- the proposal of the ideas of infinity and continuity in architecture.

In the second half of the twentieth century, the curvilinear shapes of the Trans World Flight Center in New York by Saarinen were considered to be the coordinates of the architecture of the future; spiral main massing and the structure of the exposition-the ramp in the Guggenheim Museum, built by Wright; cities lifted on columns by Le Corbusier and Khidekel, a multi-layered city by Fridman, a spatial city by Schulze-Fielitz, spatial structures for the cities by Le Ricole, 'suspended cities' by Maimon, the cybernetic city by Sheffer; mobile architecture of dwellings, theatres, cities by Ruhnau, Fridman, Guy Rottier, Shein, Manian, Coulon; 'living' structures by Helmke, Otto, Soleri, Griyo; sphere- and egg-shaped forms of experimental buildings by Hauserman, Quarmby, Githe; architecture / sculpture of Gereth, Cuell and others. Architectural ideas of their main generator in the twentieth century-Kiesler (ill. 3).

However, did the predictions of the architects / futurists of the twentieth century come true in the twenty-first century, or did they partially come true and is there a place for sprouts of architecture, which is associated with 'architecture of the future' of the twenty-first and twenty-second century, which have already been born and bloomed and nobody in Ukraine has thoroughly studied.

\section{Analysis of the latest research studies and publications}

At the beginning of the twentieth century in Ukraine, the rules and principles of the international style

III. 2. A Walking City. Archigram (https://revistabifrontal.com/archigram-la-arquitectura-como-rebelion-nomada/ accessed: 10.02.2020)

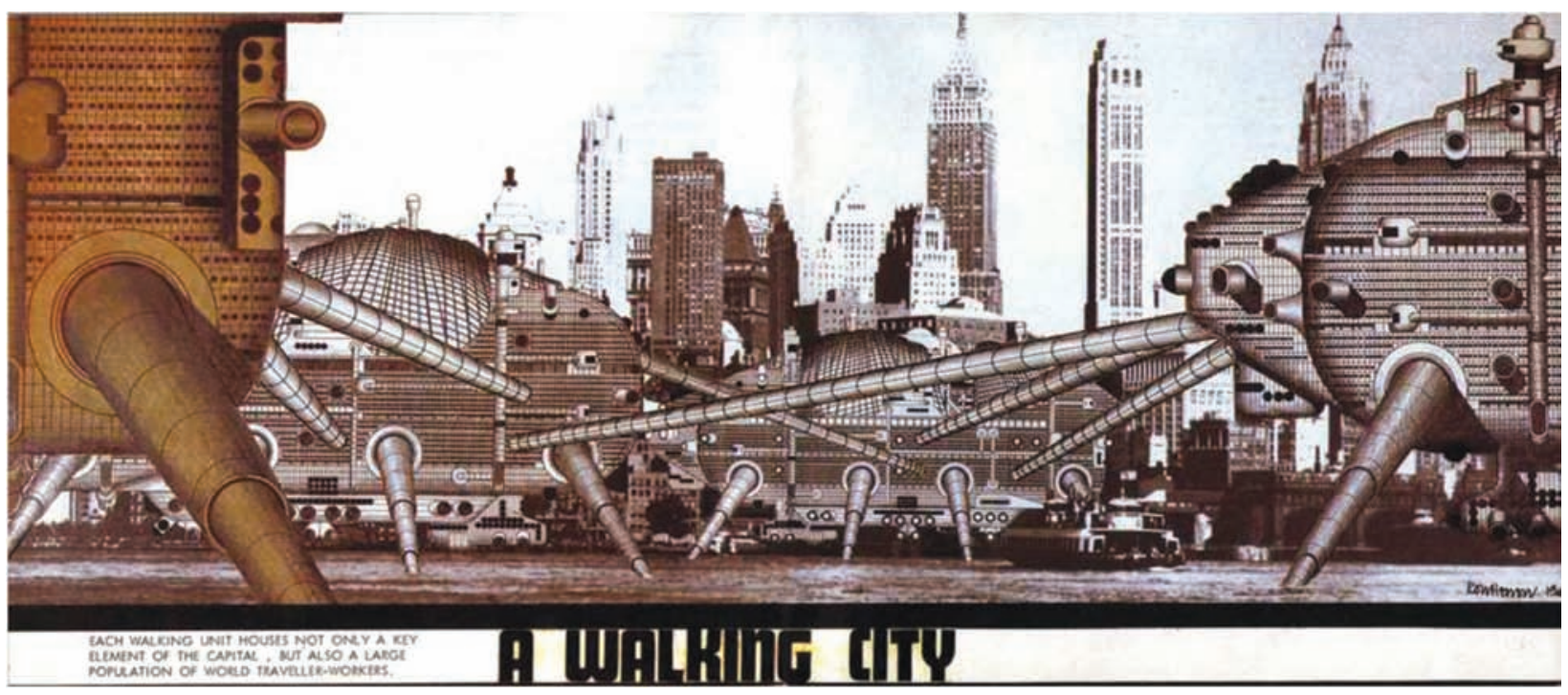




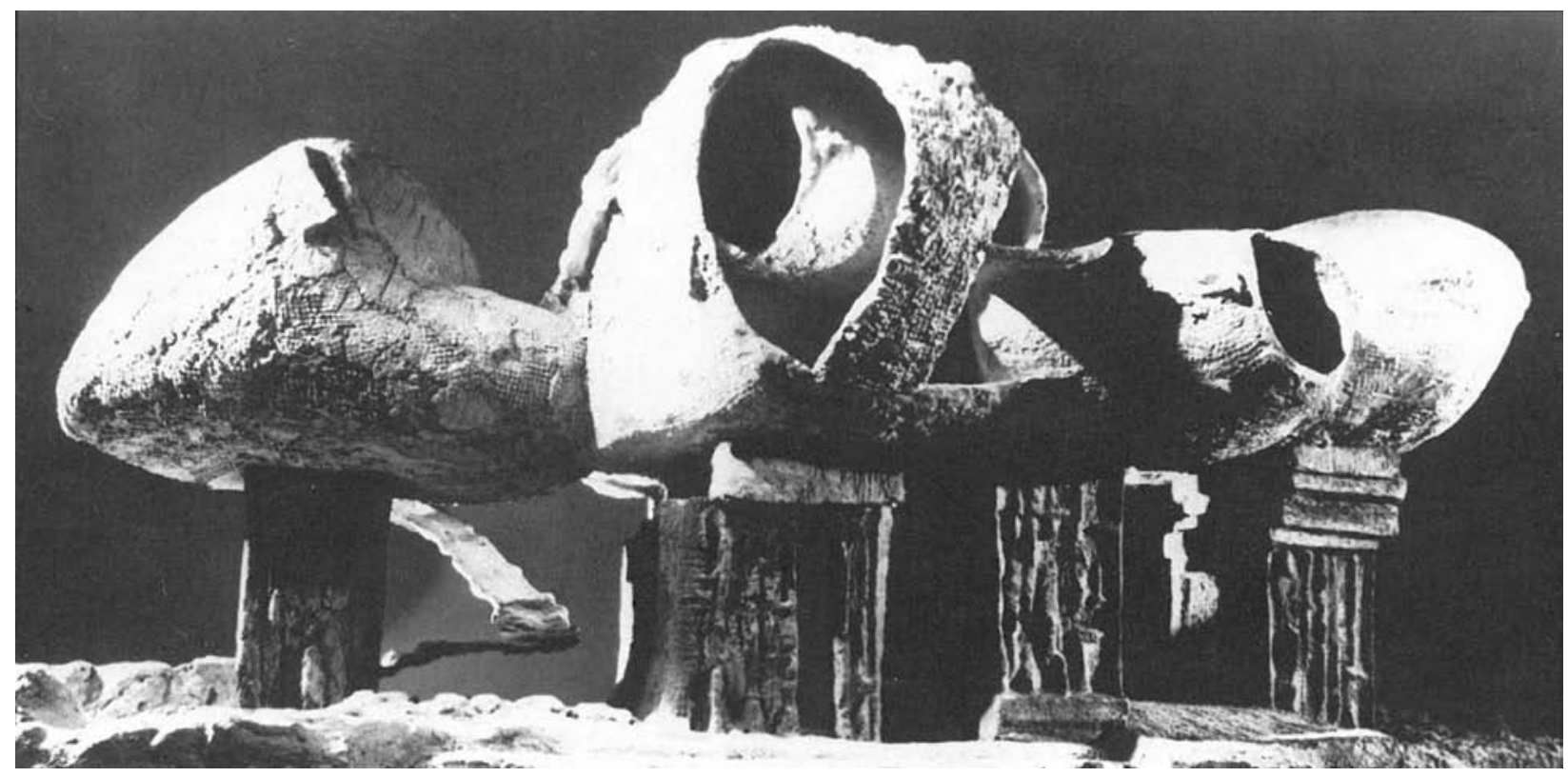

III. 3. A model of the endless house 1959. Frederick Kiesler (https://www.nytimes.com/2015/08/28/arts/design/review-endless-house-expands-the-definition-of-home.html accessed: 14.03.2020)

have been absolutely exhausted, which was considered to be completely reliable from the point of view of architectural activity principles until recently. The most important thing is that in the independent state people refused the doctrine and conception of Soviet architecture, which had a strict architectural typology of buildings and structures as its foundation at both the level of ideological categories and the most primitive one, functionally vulgar typological level. In other words, the guidelines which, over the last decade, had been the example in the form of remakes from the objects of 'modern' Western and 'modern' post-Soviet architecture for creating 'regional', 'province' or capital architecture as well as artistic, emotional and intellectual support of architectural workshops at state schools in the countries, which were the part of the USSR until recently, disappeared. While practising architects have finally managed to ensure routine money-making, artistic unions and academies have hidden behind faraway perspective programmes (for 2020 and further); architectural schools-institutes, faculties, departments as well as various research institutes have not decided, what exactly can become the true conceptual skeleton of the Ukrainian architecture of the future for all creators.

Moreover, unfortunately, architecture-which among other kinds of art, like painting, sculptural arts, poetry, music which create spiritual world of a person-is also a physical part of this world and cannot wait until theoreticians develop its criteria and principles under constantly changing conditions and demands of the world. This means that the most important question of the architecture in Ukraine is whether our contemporary architects will be able to continue performing the function of the creators of architecture forms nowadays as well as in the future, and if yes, then how and which forms those are going to be.
The majority of modern architecture experts in Ukraine, for whom practicing architecture is not a hobby, consider architecture (everything what is presently designed and built) should, undoubtedly, correspond to everything that falls under the generalised name of 'our time'.

On the other hand, there are people who criticise total 'renovations', the radicalism of formal architectural solutions, protest against reforms by futurist designers of the architecture which is currently prevalent in Ukraine. They treat futuristic design as a particular detached elitism, whose main goal is to impress the client. There are also others who consider the architect to be the spokesman for the collective ideas of society. There is also a third group (both young and older people) that has by far neither a radical nor a conservative attitude. They are convinced that futuristic design in historically formed environment will lead to aesthetic and spatially subjective chaos, to an entire era of architecturally stylistic uncertainty.

Therefore, we-those who are responsible for education of future architects, who have the knowledge of the teachings of the 'pioneers', 'great masters', 'inter-style designers'-are required to take moral responsibility for the entire Ukrainian environment, the architectural one in particular. This requires a lot of courage.

The first thing that has been declared at Lviv architecture school was that the solution to the problem of the attitude towards architecture should be a total one, it is not possible to succeed by having single achievements in a certain direction or style (no matter how successful this style may be) or in modern forms, functions, kinds, types of architectural art. Therefore, it is necessary to set up principles 
of architectural education, that would enable the definition the conceptual principles of the very profession that the teachers of the school follow and encourage their students to follow, which are to create the architecture 'of the future'. Recently, a wide range of educational directions has been formed at the Lviv architecture school-the Institute of Architecture and Design: architecturally typological design, subject, landscape, light design; monumental/culturological/scenographic design, and within the last few years-urban design. These directions feature various forms of educationally applied teaching at the departments and futuristic projects in the form of international and national student's project seminars and competitions have become their important component. The results of this activity are reflected in the research works and publications of professors and teaching staff of the Lviv architecture school-V. Proskuryakov, Yu. Bohdanova, I. Voronkova, Yu. Dzhygil, B. Goi, M. Yatsiv, S. Ivanov-Kostetskyi, Z. Klymko, O. Kordunian, I. Kopylyak, O. Krasylnykov, O. Proskuriakov, R. Stotsko, Yu. Filipchuk, K. Yanchuk and others. They include studies of certain aspects of architectural practice and theory which can be considered as a pursuit of the architecture 'of the future' both in Ukraine and around the world. The representatives of other architecture schools of Ukraine follow a similar trajectory: O. Kutsevych, V. Tymokhin, N. Shebek, L. Kovalska-from Kyiv; G. Osychenko, O. Remizova, O. Smolenska, K. Cherkasova-from Kharkiv; V. Vadymov, V. Shulyk-from Poltava; T. Tovstyk-from Dnipro; V. Meshcheriakov-from Odesa; I. Korotun-from Chernivtsi; I. Abramiuk-from Lutsk and our colleagues from the Dresden University of Technology-B. Harbaum and D. Hamman; from the Kielce University of Technology (the city of Kielce)—L. Kamionka, V. Kozub, S. Wehle-Strzelecka; from Ryerson University (Toronto)-P. Bosyy and others.

However, there is an obvious lack of research which can be the basis for the final conclusions regarding the architecture genre palette which will appear around the world and in Eastern Europe, in Ukraine in particular, in the near and far future.

Regarding all that has been mentioned above, issues presented within the last few years at the international conferences in the Lviv architecture school and, most importantly, the ones which took place in 2018 and 2019 - an international scientific conference 'On the way towards architectural education and profession of the future' and 'Genesis and the development directions of the architecture of the future in the Eastern Europe' may be of particular interest.

\section{Objective of the paper}

The aim of this paper is to analyse and present the pioneering architectural achievements in the form of ideas, projects, buildings, discussed during the presentations at the international scientific conferences 'On the way towards architectural education and profession of the future' and 'Genesis and the development directions of the architecture of the future in the Eastern Europe' which are associated with the future.

\section{Presentation of the main material}

To summarise the issues discussed at the conferences mentioned above, all the presented predictions regarding the architecture 'of the future' can be combined in the following way:

\section{First. Predictions of architects / educators}

V. Tymokhin, an architect, scholar and theorist who is well-known in Ukraine (D.Arch. at the Department of Architectural Environment Design at the Kyiv National University of Construction and Architecture, Ukraine) has highlighted one of the possible approaches towards forming ideas about the space of architectural environment from the point of view of ornamentalism. F.L. Wright followed it when he defined ornament as '...the development of a feeling of constructing an architectural object as a whole or finding an abstract logic of the structure'. The author mentioned that ornamentalism in its usage to analyse and synthesise of an individual space of an architectural environment has great potential and capabilities for the mutual integration of scientific, artistic and philosophical knowledge and values. The crystallisation of new architectural and environmental ideas in the saturated with these values space, where in the hierarchical grids of frontal systems, on the kaleidoscopic canvas and rhizome nets magnificent ornamental patters are being born, in the future will undoubtedly assist in losing the curtain of the mystery from the miracle of life-giving creation and self-organisation of visible and not visible space of an architectural environment (Tymokhin V., 2014, p. 9-11).

When it comes to the pedagogics of the artistic creativity in the modern Ukrainian architecture school, O. Remizova (D.Arch., Department of Architecture Fundamentals at the Kharkiv National University of Building and Architecture, Ukraine) pointed out that the modern system of architectural education in Ukraine was formed as a whole during Soviet times and is undergoing significant transformations. Moreover, this process has not been reflected on so far. According to Remizova, one must ask the question: what are the ways out of the situation which has been established in architectural pedagogics? The presenter considered one of them to be the modernisation of artistic creativity methods at architecture schools, in particular: problematisation of teaching project and research tasks on the basis of real conditions and problems of historical cities will help activate the studying process, will make students look for and find solutions. This method is aimed at preventing the mechanical increase in information volume from different subjects.

Analysis of the key works on the subject of dwellings, presented by Yu. Dzhygil PhD Arch., which was performed the Department of architectural environment design during the last fifteen years, indicates a certain evolution of this subject palette-from following the typological standards of the past to topical modern tendencies 
in architecture and design. At the same time the authors addressed the most pressing problems of modern days-social, ecological, culturological and others.

In his paper, Ja. Niewada-Wysocki (Department of Civil Engineering and Architecture at Kielce University of Technology, Poland) has discussed the current forms of cooperation between the Department of Architectural Environment Design of the Institute of Architecture at the Lviv Polytechnic National University and the Department of Civil Engineering and Architecture at Kielce University of Technology in terms of educational and exploratory design. In 2011 in Lviv, having signed a cooperation agreement, the Lviv Polytechnic National University in Lviv and the Kielce University of Technology in Kielce declared joint measures aimed at improving didactic processes as well as exchanging academic experience in various directions, the most important of which were educational and exploratory design. At the beginning, such projects were coupled with semester papers, lateras Bachelor and architectural and engineering diploma projects of Ukrainian students in the environment of Kielce and the Polish ones-in Lviv. The buildings and structures in other cities of Ukraine and Poland were the next direction of design. In the future, it might be possible to have obligatory student's pre-diploma design internships at the practices of 'mature' architects-Ukrainian ones in Poland and Polish ones in Ukraine.

In the author's opinion, such an arrangement of educational design will help Ukrainian and Polish students to be a part of international groups; to use the knowledge in the sphere of architecture in a syncretic way; to get professional experience directly from the well-known practicing architects, get acquainted with their design methods both in Ukraine and in Poland, see the similarities and differences, find the authenticity, synthesis etc. (Niewada-Wysocki Ja., 2018, p. 73-77).

\section{Second. Futuristic ideas of practising architects}

Architect $\mathbf{O}$. Kordunian (a practicing architect, PhD Arch. from the city of Chernivtsi, Ukraine), leaning on his own extensive design experience, presented his view on the formation of contemporary and future architecture in Ukraine. The appearance of multi-purpose designer architecture buildings is the first and primary sign of new negative tendencies. It does not assist in the total spreading of stereotypical, universal and typical 'products' and creates a 'one-size-fits-all' world, which is very quickly becoming fashionable but also standard one and causes a viral effect in the environment. The second one is the formation of the modern Ukrainian architecture under the excessive pressure of the bureaucratic apparatus on the architectural profession, the influence of non-professional tastes and interests of the private sector which do not coincide with the professional and public intentions: imposing of the market of the 'modern' building decorating materials that creates a myth about 'modern' architecture as an architecture exclusively made of metal and glass. Solving these problems should start from the basics. The first step should be giving restoring authority to the profession. It is not quantitative, but qualitative characteristics of architectural education should be play a defining role. The task of the architectural schools of Ukraine lies in forming the culture of understanding the reasons behind the development of client-designer relationship of the modern architectural ideas. Education faces global challenges: either to beat in the tail of the progress and blindly follow foreign architectural ideas, connecting them to local needs, or to look for its parallel path towards new progressive architectural ideas based on the logical development of its own local experience. This second way will be the one to lead to the uniqueness of the modern Ukrainian architecture in the equal limitless artistic spectre of the variety of the world architecture.

While studying futuristic design as a predicting set of instruments, S. Ivanov-Kostetskyi PhD Arch. formulated conclusions which might become the basis for architects, designers and futurists in their research of the future. Obviously, not in the specific designing questions, but in the general direction of developing ideas. The 'technical' aspect of form creation in environmental conditions, which is currently predominant, is by far not the only way of development of environmental design culture. That is, an architect-artist of the environment should know and be able to do everything in his design process at work: master the achievements of contemporary and traditional art, achievements of scientific and technological progress, folk fantasy, regional culture forms, people's creative activity etc.

The main feature of the world of the future looks like the all-round development of an informational field of human existence, which is currently comprised of the aspiration for knowledge, ability to communicate and creative obsession with the dominant feature of lifestyle. In other words, the development of services, transport, the rise in environmental comfort (in particular, with the help of the various types of 'gadgets'), increasing manufacturing powers are not the aim but the means of improving human existence. Thus, then harmony and coordination of forms, which are associated with the term 'beauty', will be the main features of the environment. It is the beauty of our surrounding that gives us the optimal impulse to move human nature into the future (IvanovKostetskyi S., 2014, p. 12-19).

Researching the models of urbanised systems of the future, A. Fitio (a consultant on the local economic development and strategic planning, Lviv) concentrated his attention on 'cyberphysical systems'-informational and technological concepts which deal with the integration of computing resources into physical entities of any kind, in particular, into biological and man-made objects.

At the beginning of the twenty-first century, humanity is storming the era of the total digitalisation and robotisation which will undoubtedly make its mark on the vital activity and spatial arrangement 
of individuals, especially on the labour market when technological processes such as equipment or clothes production will be conducted without human participation, when there is no need for production facilities with natural lighting and ventilation. The production cyberphysical systems does not require lighting or sanitary and hygienic demands regarding premises, which are obligatory for people. Such activity can be conducted underground.

The peculiarity of placing production facilities underground minimises another problem-heating expenses. Forming underground automated factories will make it possible to considerably expand existing above-ground territories of urbanised systems, which is extremely important in the conditions of turbulent natural and climatic changes.

\section{Third. Features of the architecture 'of the future' found by architects / scholars}

In her paper Architectural metamorphoses in the libraries of the future, I. Voronkova argued that it was the turn of the twenty-first century that became the turning point for library architecture and their activity in general. First of all, it happened because of fundamental changes in realising the significance of a library to society. The modern generation has challenged the old library by creating a completely new library space-a space where concentrated work and entertainment, new technologies and creativity, studying and perception of the world are combined with places for meetings, communication and group projects. Openness, accessibility, comfort, multi-functionality, self-service, quick processing of information and others had to become the main features of such spaces.

A new approach in cooperation with modern users has started demanding greater attention to creating an individual architectural image for libraries, the pursuit of an image, increasing prestige in the surroundings of their regular and potential users. It has already borne results: library buildings have currently been given an entirely new meaning, their architecture has become a reflection of new paradigms - an informational and a social one.

The paper by I. Humennyk The development of landscape theatres of Ukraine in the future describes the ways of developing the architecture of landscape theatres of Ukraine in the future and the tendencies and directions of the forms of creating open-air theatres in various climate zones of the country. Global warming process have created favourable conditions for a considerable increase in the expected use period of open-air buildings in various climate regions of Ukraine in park, urban and historical places within populated areas. In the twentyfirst century, there is a tendency among authors who reconstruct and design new landscape theatres to turn to the historical origins of the performing traditions of the Ukrainian people and the ability to widely use the new multimedia technologies and electronic technical tools. Due to the scientific and technological progress, this should be considered an important modern factor. Bright lighting, high-quality sound, various special effects, using the virtual environment in the process of creating scenography of cultural activity and performances with an actual landscape in the background create new possibilities for enhancing the influence of theatrical performances on the emotional state of the audience. As a result of the previous design research, the author claims that all theatrical buildings which are located in the landscape in the open air, and include objects of both anthropogenic and natural origin, should become an inevitable composite of the leisure buildings 'under the open sky' in the future (Humennyk I., 2018, p. 32-37).

Modern societal development tendencies indicate that there is a strong need for having spaces for cultural activities, communication and leisure. While researching the genesis and development of architecture of club buildings, architect I. Kopylyak established the following: In the nineteenth century, the first more democratic, generally accessible clubs with a wider leisure programme started appearing in Europe. Such clubs included: a Sunday school, a library, space for entertainment such as sports and audience halls, billiard room and rooms for playing cards.

In Ukraine, rural and urban cultural and educational buildings were often quite different in terms of their visual and architecturally spatial solutions. A traditional Ukrainian house as well as a church can be considered as prototypes of Ukrainian clubs in villages. The ones in cities were mostly based on European patterns.

Social, economic and ideological conditions of every historical epoch made their own marks on the types of public buildings and urban spaces, providing them with a new social meaning and functional structure.

Therefore, in order to foresee the development of modern cultural buildings, define their optimal functional structure and object and spatial solution it is necessary to analyse and use international and national architectural experience, especially the one of the end of the nineteenth-beginning of the twentieth century when public buildings were becoming most popular (Kopylyak I., 2019, p. 30-34).

In his paper The designing principles of a student's medical centre of the future the master $\mathbf{O}$. Krasylnykov touched upon the role of architecture in the creation psychological comfort and its positive effect on human health. The author analysed modern tendencies of medication space arrangement in modern medical institutions, that might become the basis for creating youth medical institutions in the future. Contemporary researchers consider a person's existing conditions in the physical environment to have a greater impact on health than genetic susceptibility to illnesses. Architecture, being an obligatory element of the physical world, is always present in a person's environment, mostly in the buildings of the functional purposes and 
this makes it a highly effective manipulator of the consciousness. The effect of architectural manipulation can have alternative manifestations (with favourable or adverse effects) and the suggested design solutions can favour the health improvement or, vice versa, illness progression. In order to change the outdated practice of arranging space in medical institutions, it is necessary to address new approaches which have started developing within the last 20 years in a syncretic unity of architecture, psychology and medicine and which have not stepped over the boundaries of being just experimental solutions. As surveys have proven, students assessed architectural solutions that have been used for designing state medical institutions, very strictly. They reported inconveniences and aesthetic discomfort while being at 'modern' medical institutions and insisted on changing the concept of architectural design of youth medical institutions. The author considers the search for unconventional solutions in designing student medical institution buildings to be one of the main tasks of futuristic design (Krasylnykov O., 2018, p. 64-68).

K. Yanchuk explained the architectural and theatrical ideas of F. Kiesler and their influence on Ukrainian and global architectural practice. Despite the fact that the majority of F. Kiesler's ideas were never implemented, they had direct influence on the designs of architects of the second half and the end of the twentieth century who, in search of modern approaches to design, were actively researching the heritage of the artist. The author conducted an analysis of the project The Endless House, a residential building on the props for Paris, infinite and multipurpose theatres which were the subject of F. Kiesler's activity and modern architectural works where these ideas are reflected. $K$. Yanchuk concluded that in the modern world, projects with dynamic rounded shapes, without straight angles and strict functional separation are appearing more and more frequently. Even though other designers are their authors, following F. Kiesler's ideas is extremely noticeable, since he had developed them many years ago in order to create a certain palette for all future followers (Yanchuk K., 2018, p. 116-119).

Fourth. The activity of the architects / educationalists, practitioners, and scholars on the path from the dream about the architecture of the future to the measures of creating it

For many years, architect M. Yatsiv PhD Arch. has been defining development directions for artificial illumination systems and the expansion of their utilitarian and decorative functions in architecture. He claimed that it is possible to predict with a high degree of probability that the systems of electric lighting in religious spaces of the churches of the future are going to be improved with both the development of illumination technologies and the search for designer solutions in the arrangement of forms of the lighting environment of cathedrals.

Most probably, dynamic lighting (instead of fixed lighting) will be the dominant method of electric illumination and it will depend on the type of the liturgy and will direct the attention of church visitors to the important moment of the liturgy and assist in helping people to concentrate on prayer. At present, there are professional lighting systems which are set up and equipped in a way that meets the needs of a certain church. The separate schemes (there can be even a few hundreds of them) are grouped into lighting zones, which makes it possible to implement dozens of lighting scenarios with various lighting modes. It is possible to operate the illumination system using computer programs for controlling various light sources. They make it possible to change the lighting intensity and maintain a constant level of illumination intensity in the church depending on the time of the day and the character of natural lighting. There are no issues with setting up electric lighting with the aim of programming various light intensities for liturgies and other religious rituals. At the time when liturgy is not conducted, the lighting can, on the one hand, emphasise the architecture and the interior design of the church, giving the opportunity to admire them and, one the other hand, set a mood which is favourable for a quiet, individual prayer, concentration and spiritual feelings (Yatsiv M., 2019, p.115-120).

In his work Creative coordinating qualities in architectural education and on the way towards the profession of the future L. Kamionka (D. Arch., the Department of Civil Engineering and Architecture at the Kielce University of Technology, Poland) explored education problems in the field of architecture and urban planning at the secondary level in the form of a pilot programme and in the education of Bachelors and Masters of Engineering in Architecture. Coordinating the process of forming the surrounding environment by a person is the main feature of the education and a professional activity of an architect. Regardless of the fact whether he works in a small team or for a big company, the complexity of an artistic process as well as the scale of the activity make him responsible for spatial transformations and design process coordination. Close cooperation with manufacturing designers and experts on construction management-at every stage of the development process-is the key to achieving goals. While preparing the architects as the representatives of the profession of the future, it is important to understand the new challenges which they will have to face. The architects of the future should possess deep interdisciplinary knowledge. Most importantly, they should know how to work with team coordinators and be willing to persuade people to support the suggested solutions. However, it is the creativity of the architects that will be creating architecture in the design process. Architecture cannot exist without creativity and aesthetic value (Kamionka L., 2018, p. 49-53).

Analysing urban landscapes, Yu. Bohdanova, among other things, analysed the methods of creating such landscapes and the objects that form them. Total industrialisation at the end of the nineteenth and the beginning of the twentieth 


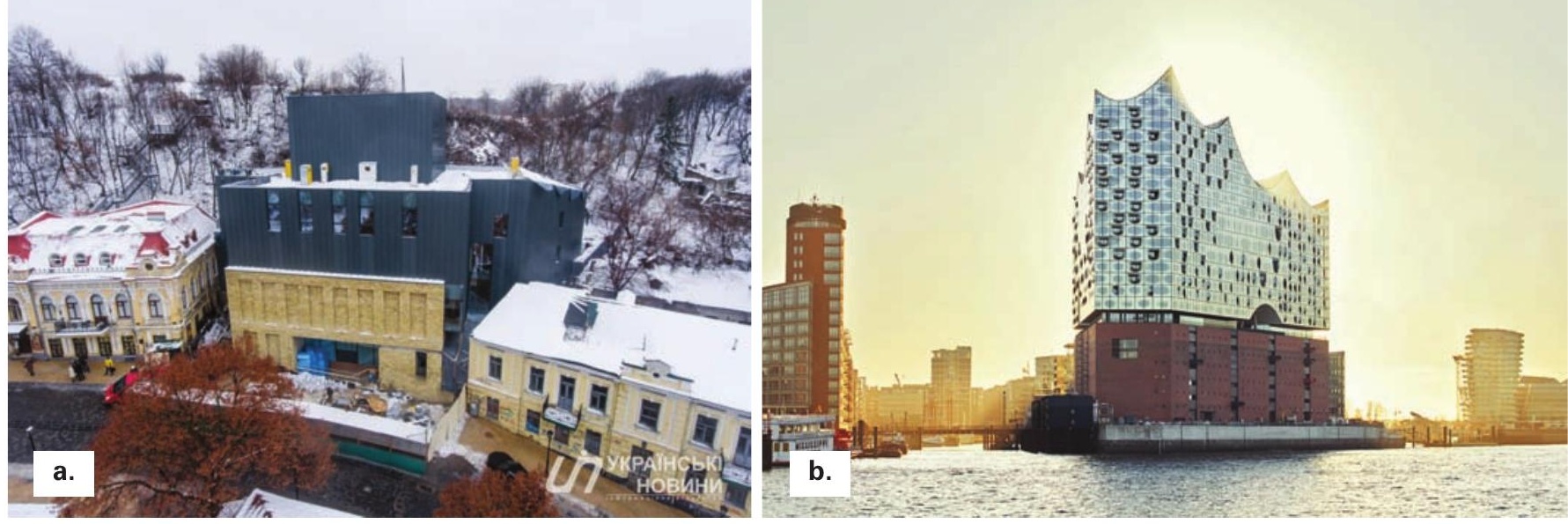

III. 4. An example of an unsuccessful and a successful siting of a building in the existing urban landscape.

a. A theatre at Podil in Kyiv, Architect O.Drozdov. (https://ukranews.com/ua/news/531857-z-byudzhetu-kyyeva-na-skandalnyy-teatr-na-podoli-vydilyly-vtrychi-bilshe-nizh-roshen-zmi- accessed: 14.09.2018)

b. Elbphilharmonie in Hamburg near the River Elbe. Herzog \& de Meuron. (https://zefir.ua/art/21505-elbphilharmonie-filarmoniya-budushhego. html accessed: 14.09.2018)

century favoured the active, sometimes spontaneous, development of cities that covered large territories with the construction of new residential areas. Even 'controlled' twentieth-century planning could not overcome the development density which was turning the environment of human existence into 'stone jungle'. At present, cities are not developing outwards so actively, there are attempts to fit new buildings into already existing urban tissue. The contemporary stage of architecture development, when quick exchange of the information is inherent, creates big opportunities for non-critical usage of the experience of other countries in the sphere of architectural design. Unfortunately, while borrowing foreign experience, Ukrainian architects bring it to Ukrainian grounds without considering that the building chosen by them will be located in a completely different environment (ill. 4a, 4b).

As early as during the design proposal stage, the building is suggested without taking into account the urban landscape it is designed for, and is being created as detached from reality. It leads to a situation that during the building's adaptation to the conditions of its intended environment, in spite of all the innovation of its architectural and presentation solution, there is an unjustified condensation of the building area, it disharmonises the aesthetics of the street spaces and leads to functional inconveniences in the area's use. It is currently important for architects to not only design a unique, large and significant building, but also to be able to professionally integrate it into an existing environment of an urban landscape. The comfort of inside such a building is and shall remain the goal of architects in the future; it is, in particular, the functional, aesthetic and environmental comfort (Bohdanova Yu., 2018, p. 11-14).

The aim of the presentation by $\mathbf{S}$. Wehle-Strzelecka (D. Arch., the Department of Civil Engineering and Architecture at the Kielce University of Technology, Poland), entitled A modern European city - challenges, prospects and the view of the world was to define and describe the problems connected with the development of modern cities and the possibilities of activities in architecture and urban planning that would help form an urban space that is favourable to residents. The presentation was also aimed at participating in the discussion about the role of the modern city and its future in connection to the ongoing processes of urbanisation and changes in the social structure of European cities. The author defined two problematic directions. The first one concerns urbanisation processes, while the second onethe demographic problems of modern cities and their influence on design proposals. The expert proved that architectural and urban solutions have to be directed at the implementation of a concept of a harmoniously arranged city in social, spatial, economic and ecological aspects. However, especially in the different countries of the European Union, there is a movement that is common to all these tendencies, which lies in the development of two fundamental concepts: the idea of the eco-city (Ecopolis) and the sustainable (well-balanced) city. It is connected with the approval of a new cultural paradigm which lies in willing to limit the consequences of economic activity, including expenses on urbanisation both in terms of a person's attitude and the entire natural environment. Within re-urban activity, a direction towards renewing central territories in cities has been chosen. In essence, it can be assumed that in the boundaries of architecture and urban planning, there is a pursuit of implementing the concept of a city which is universal, smart, friendly to residents, established in terms of a historical, social, spatial, economic and ecological aspects. It is also suggested to combine cities into s network with various tasks and functions in the future (ill. 5a, 5b) (Wehle-Strzelecka S., 2018, p. 89-94). Researching artistic glass in architecture, V. Kozub (D. Arts, the Department of Civil Engineering and Architecture at the Kielce University of Technology, Poland) emphasises that artistic glass has unique physical and aesthetic qualities and, therefore, is characterised by unique means of influence on the architectural space. Glass ensures a wide range of artistic possibilities, which are achieved with its help by creating the scenic and sculptural images in architecture. Constant development of machinery 


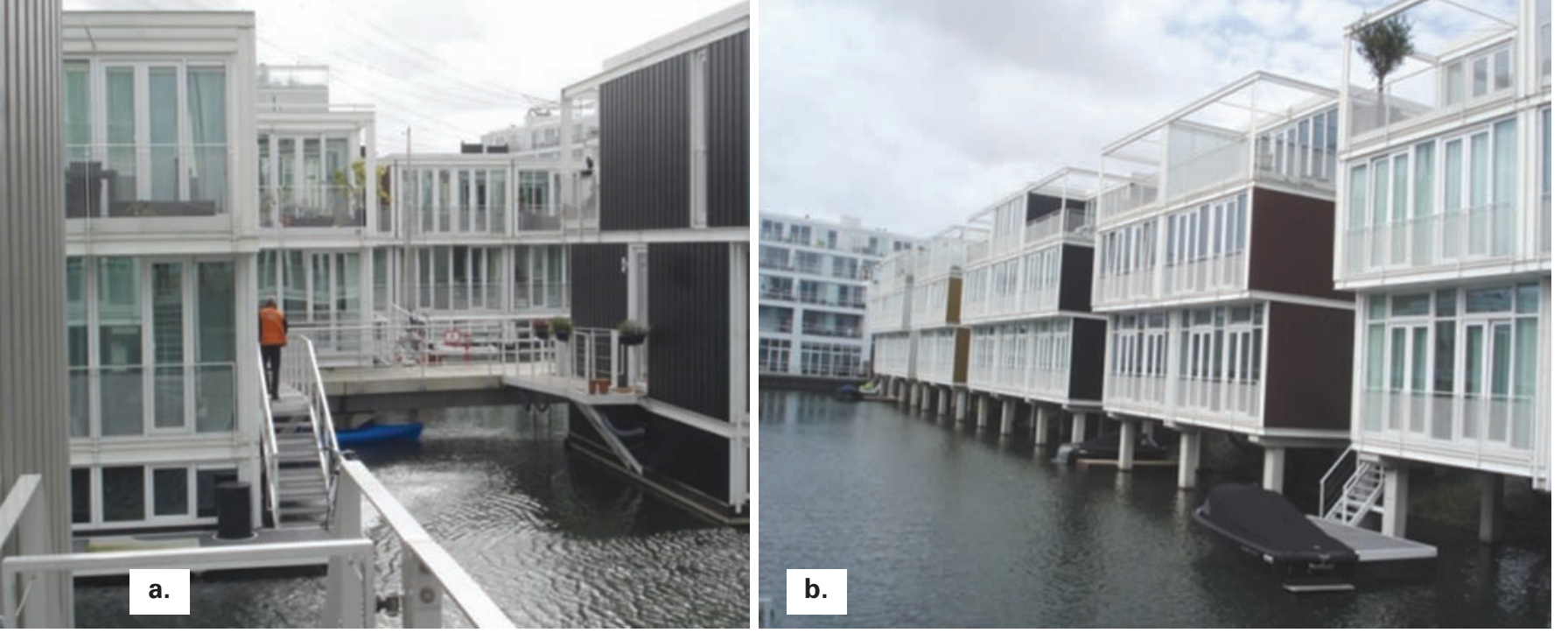

III. 5 a, b. A building at ljmer lake in Amsterdam. Photo by S. Wehle-Strzelecka

and technology as well as a continuous evolution of art broaden the palette of possibilities of the artists, thanks to what their artistic thinking is becoming more and more brave. There is no doubt that in the future it will be more and more eagerly used in architecture (ill. 6) (Kozub V., 2019, p. 23-29).

B. Harbaum (the Department of Urban Planning at Dresden University of Technology, Germany) in his presentation Controlled cities as an urban approach towards designing small towns in the future by the example of small towns of Saxony (Germany), discussed their functioning peculiarities on the example of the towns of Saxony. The previous author's works on this topic had allowed him to check their result in the discussions regarding good quality of life in the city and reach the conclusion that not enough attention is paid to the question of state planning of the development of such settlement areas. Studying the architecture of small towns in Saxony as part of academic and pedagogical work at the Dresden University of Technology took place at the beginning of 2015. The precondition for this work was a request by the workers of the Department of Monument Protection of the state of Saxony, where the critical state of preservation of historical small town layouts had been noted and mostly because the buildings in historical centres of such towns had been ruined by their owners due to the absence of prospects for their further preservation. It concerned not only the dismantling of individual buildings but, in some cases, also of the parts of urban complexes as well as entire streets. The author concludes that in small towns, as well as in rural areas the loss of individual buildings and complexes in historic centres is a loss of certain cultural values and, therefore, of the quality of life of the residents of such cities. The author suggested the following methods of a controlled development of modern small towns: creating the network of environments of 'the background spheres of social life' which create high-quality proposals of everyday servicing and the usage of historical structure of the towns; involving residents into the process of shaping their surroundings; considering the question of interaction between people of different cultures; activating the study of change of forms of use of a residential and public arrangement of small towns by means of applying modern digital technologies in retail (Harbaum B., 2019, p. 21-26).

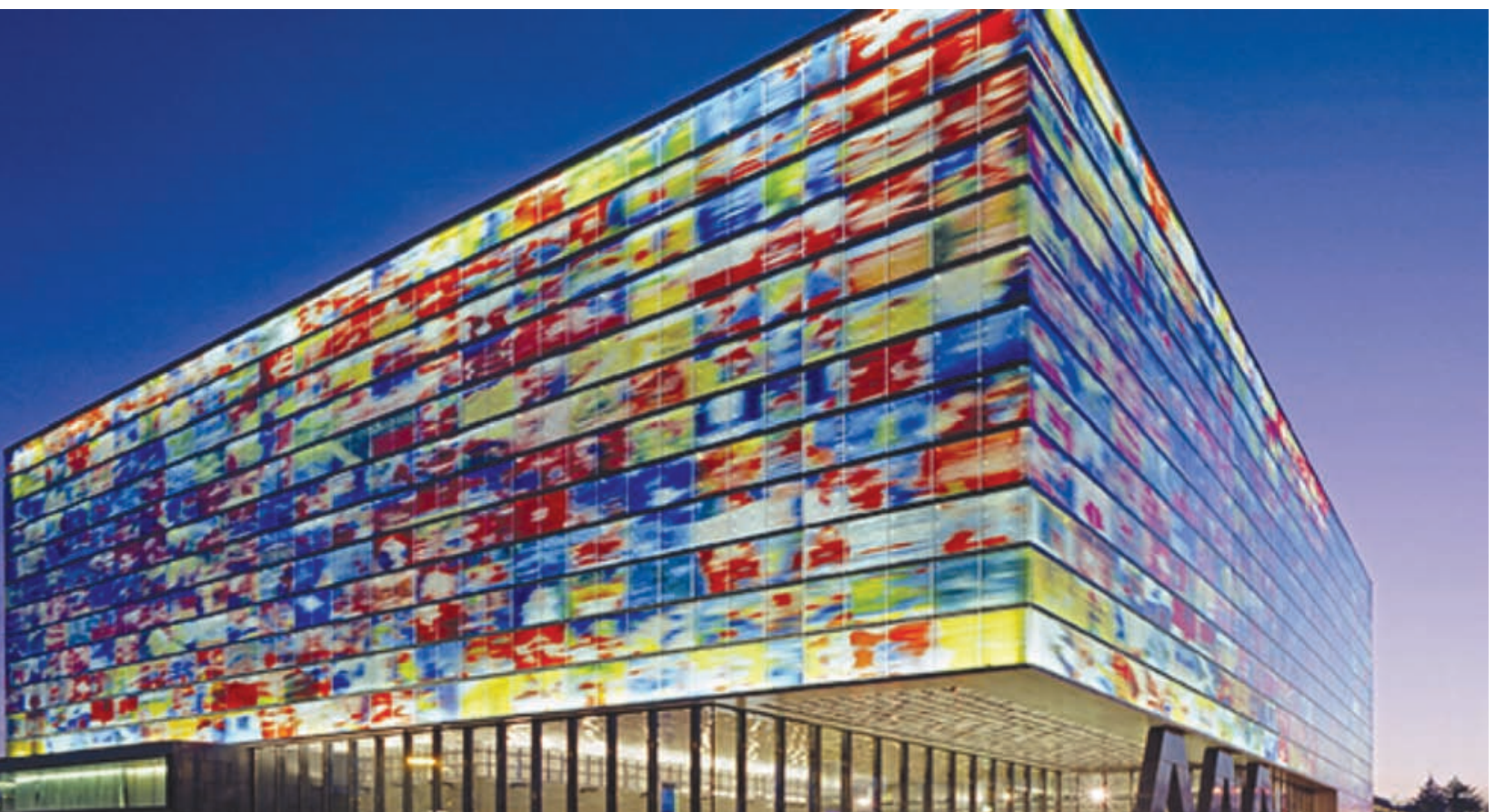



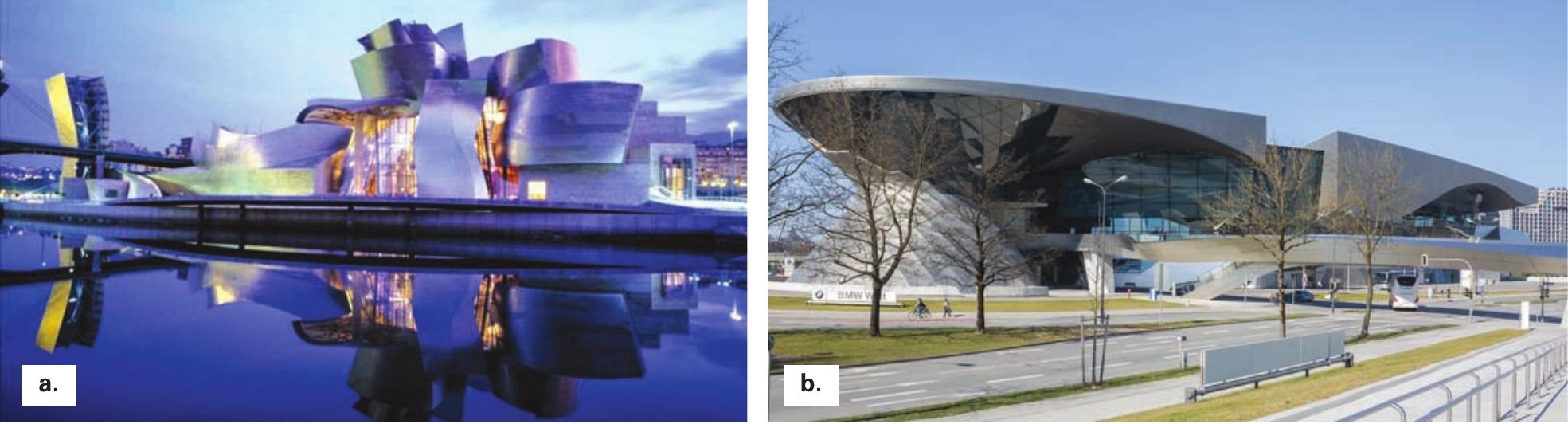

III. 7a. Guggenheim Museum, Bilbao, Spain. Gehry Frank Owen (https://yuxiangwei4521.wordpress.com/2010/06/07/retrospective-interior-design-the-twist-world-of-castles/ accessed: 14.03.2020)

III. 7b. BMW Welt (BMW world). Architecture bureau Coop Himmelb(I)au (https://commons.wikimedia.org/wiki/File:BMW Welt,_M\%C3\%BAnich,_Alemania16.jpg accessed: 12.02.2020)

An architect, scholar and a practitioner, O. Proskuriakov, known in Ukraine and Austria because of his defended dissertation about the architectural principles of F. Fellner and H. Helmer society, stated that the futuristic movement, from which people expected certain steps towards future architecture, faded unnoticeably in the 1990s, without producing anything that could grow into an architecture of 'a new generation' of a human civilisation. It concerns both the 'Western' architecture and the 'Eastern' architecture, to which Ukraine belongs.

All the experiments of the architects F. Gehry (ill. 7a), O. Eliasson, Coop Himmelb(I)au (ill. 7b), Z. Hadid, H. Hollein, D. Libeskind, G. Domenic, P. Eiseman, G. Banham, P. Cook and others-these are one-time experiments in the direction towards new construction materials, technologies, structures which are impossible to be produced in a 'mass-exclusive' way because of the 'exorbitant' building prices which are more akin to exhibition pieces for world fairs than ordinary buildings. In Ukraine there are other tendencies-at the turn of the century, the leading architects of Ukraine are sometimes willing to copy remarkable architectural solutions of their western colleagues, rather than finding such architectural algorithm which would allow to base on the national architectural achievements, found in Ukraine. It is done in order to look like modern, upscale, fashionable architects (ill. 8a, 8b) (Proskuryakov O. V., Yuriychuk R. D., 2019, p. 57-62).

\section{Conclusions}

The historical development of architecture has been going its way from the past into the future. For us, architects, it is scientific prediction, which is extremely important today, as it reflects the entire complexity of modern life which is distinguished by a constant competition of social, scientific and cultural progress with everything historical. The main feature of predicting the architecture of the future has to be not only a search for the newest technical and technological construction means, but, most importantly, scientific predictions concerning political, ideological, social challenges, and the complication of lifestyle of the communities, the evolution and transformation of the structure of societies, life, everyday routine, work and leisure of people who form them not in an isolated way within their own countries but in the settlement systems of entire continents, especially those which are close and connected by historical, cultural and mental memory. Architects have to take moral responsibility for the entire architectural environment. It is only possible by changing the attitude paradigm towards architecture and the architectural environment which, in the nearest future, should be a total one, in no way t separate achievements in a certain direction or style (no matter how successful this style may be) or in forms, functions, kinds, types of architectural art, can be successful. It is related to architectural education, architectural science as well architectural practice. What questions are the most important in the world during the last years of the twenty-first century? They lie in the following:

First. Is the profession of the architect final? In other words, can the professional architectural tasks be solved by a representative of another profession,

III. 8a. Martin Luther King, Jr. Memorial Library, Washington. Ludwig Mies van der Rohe. (http://modernesia.blogspot.com/2009/11/martin-luther-king-jr-memorial-library.htmlaccessed: 13.02.2020)

III. 8b. Europe Shopping mall. Dnipro, Ukraine. O.Dolnyk. ( http://lotosbeton.dp.ua accessed: 13.02.2020)

a.

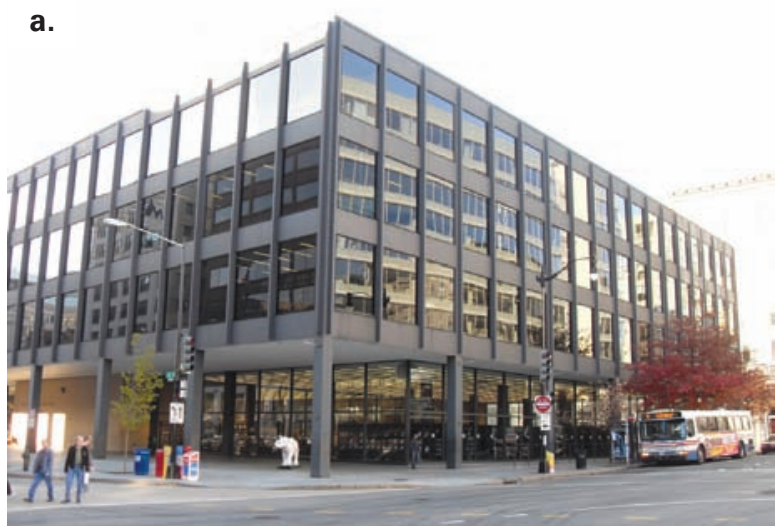

b.

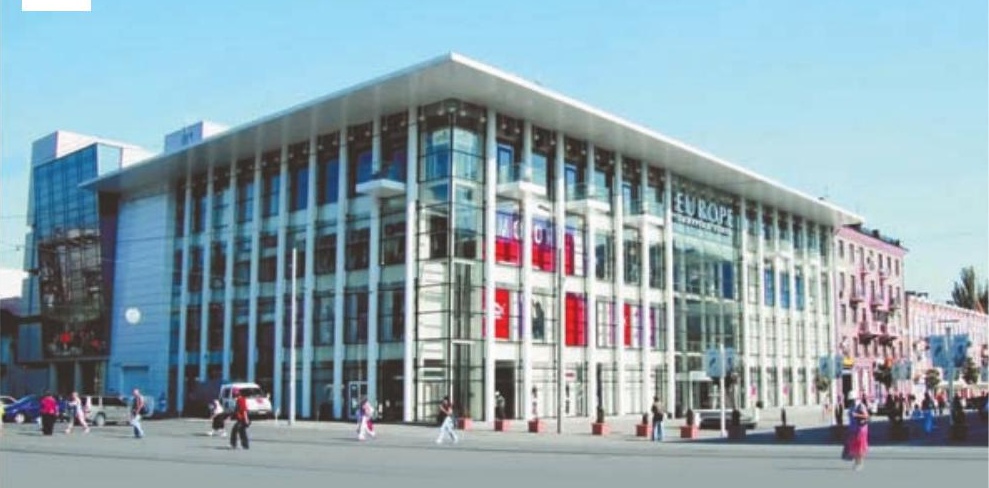


since it is facilitated by various technologies at an extremely high level, a spectrum of any construction materials, a wide palette of artistic and aesthetic means and measures, available to the average user. What does this mean for educationalists? It means that professional architecture may become unnecessary in the future!

Second. Does modern national architecture exist? If it does, then what and how much should be in architecture in order to call it at least partially the national one? Does the modern architecture, in particular of 'the west' and 'the east', 'the north' and 'the south' exist? If yes, where is the boundary between them?

This question cannot be answered by any architecture school or a single country. It is necessary to heave a syncretic, united opinion and activity of the whole world architectural community.

In order to solve the First, it is important to teach an architect to design not only architectural elements: an object, a building, a shape, a construction that requires the education in the similar fields-knowledge of acoustics, engineering, materials science, design and construction technologies. Higher-stage design is important too-designing an architectural environment where an architect is the only expert who can create the environment not only as a visualised idea, which is formed by the laws of composition, combinatorial analysis, knowledge of styles, textures, decorations, but also as solutions which are characterised by weight, colour, lighting, extent, harmony, have a past and a future, that is, they are being developed in time.

The second one can only be solved with the help of a classical, high-quality preparation by an architect when he gains the qualities of not only an engineer but also an inventor, a thinker, a culture expert.Architectural science, which is traditionally in an exploratory state, is currently presented with a challenge of the choice of the right directions of solving complex development problems, including the development of an architectural and urban planning environment. Among the last ones, the most significant are the morphological problems of the reinterpretation of the old and providing the new architectural and urban planning forms with constitutiveness. The next level covers humanising the urbanised surroundings, which requires a reformation of the urban-forming activity of the population and its restructuring. Mutual influence and feedback loops between these problems widen their scope, adding the problems of reforming the spatial and temporal worldview and evolutionary ideas as well as their harmonious coexistence and harmonisations of architectural and urban planning environment in general. In contemporary architecture and urban planning around the world, and in Ukraine in particular, there are various ways of overcoming problems which are solved by means and methods of a complex, systemic, environmental and other approaches. One such way, which unites the achievements and removes the disadvantages of the above-mentioned approaches, is the way of urban-synergetic studies which, summarising the optimism of synergetic worldview, its humane character, in the processes of self-organisation, unites and coordinates the efforts of the representatives of all architectural disciplines in the matter of the harmonisation of an architectural and urban surroundings, opens new horizons and prospects for its self-development.

Contemporary investigations of the architectural and urban planning science have prepared the ground for emergence of a new direction in the theory of architecture. The harmonisation theory of an architectural environment has to become an integral system of the principles, methods and rules of improving the living surrounding of a person who is able to define, summarise and explain the reasons for logical transformations, which are happening under the influence of the purposeful activity of the society, as well as forecast the consequences of such changes in the future.

Relatively autonomous but system-connected chapters of a new research direction correspond to the main tasks of the theory of the harmonisation of the architectural environment. These chapters include the following: environmental morphology dedicated to researching the principles of constructing the environmental objects and environmental systems; architectural socionics directed at studying the preconditions and means of achieving a harmonious correspondence between the types of subjects of environmental activity and types of architectural environment; environmental axiology meant to systematise the values which various people and communities connect with the harmonious arrangement of the environment; and environmental praxeology directed at finding methods of the effective organisation of human activity in the architectural environment.

Strategic directions of the development of architectural environment harmonisation theory are connected with an increase of the role of philosophical grounding of various aspects of environmental activity; with the improvement of the methodological apparatus of analysis and evaluation of morphological, socionics-related, axiological and praxeological characteristics of the artificial environment; with expanding the limits of historical studies directed at finding constant regularities of evolutionary development and a potential of architectural environment; with design and implementation of new methods of research, modelling, experimental designing of environmental formations and predicting their most probable changes in the future.

Modern complex researches of architecture and a practical architectural activity towards the end of the twentieth and the beginning of the twenty-first century do not make it possible to objectively state the way architectural ideas and the objects of architectural heritage, passed on to us by the creators from the last century, have been transforming into completely new ones, which were called 'the architecture of the future' in the middle of the twentieth century. 
It is absolutely understandable that everything what was thought and implemented at the end of the twentieth century during architectural experiments would be used with a noticeable time delay in the twenty-first century as well.

The complete architecture renewal can be expected at that time in the world, when separate architectural works from 'the future' will not only appear to satisfy extremely wealthy clients but also as a necessity in the human civilisation of the third millennium. As for Ukraine, where 'architectural works of the future' are mostly remakes of foreign buildings and displays of such architecture of the future are in place, since in the solutions for separate elements, details, textures, styles the complete renewal can be expected only when the national architecture will not be viewed as an isolated artistic process but as a spatial, environmental, aesthetic model of Ukrainian and global civilisation of the future. The beginnings of it can already be seen in the futuristic projects of the architectural youth (ill. 9a, 9b, 9c, 9d).

\section{REFERENCES}

[1] Ragon Michel, 1969, Cities of the future. "Mir», p. 296

[2] Timokhin V 2014, Viability of space of architectural environment. Architecture: Lviv Polytechnic National University bulletin. no. 793, p. 9-11.

[3] Niewada-Wysocki Ja., 2018, The directions of educational and searching design at the department of architectural environment design at Lviv Polytechnic National University and the department of civil engineering and architecture at Kielce university of technology nowadays and in the future. Architecture: Lviv Polytechnic National University bulletin. no. 895. p .73-77.

[4] Ivanov-Kostetskyi S., 2014, Futuristic design as an instrument for predicting the future. Architecture: Lviv Polytechnic National University bulletin. no. 793. p. 12-19.

[5] Humennyk I., 2018, Development of landscape theatres of Ukraine in the future. Architecture: Lviv Polytechnic National University bulletin. no. 895. p. 32-37

[6] Kopylyak I., 2019, Architecture of Ukrainian club buildings. Traditions and the future. Architecture: Lviv Polytechnic National University bulletin. V. 1, no. 2 s. p. 30-34

[7] Krasylnykov O., 2018, The designing principles of a student's medical centre of the future. Architecture: Lviv Polytechnic National University bulletin. no. 895. p. 64-68.
[8] Yanchuk K., 2018, Development of F.Kiesler's architectural and theatrical ideas in Ukraine and the world. Architecture: Lviv Polytechnic National University bulletin. no. 895. p. 116-119.

[9] Yatsiv M., 2019, The tendencies of developing the systems of artificial illumination of modern eastern Christian churches. Architecture: Lviv Polytechnic National University bulletin. V.1, no 2s. p. 115-120.

[10] Kamionka L., 2018, Creative coordinating qualities in architectural education and on the way towards the profession of the future. Architecture: Lviv Polytechnic National University bulletin. no. 895. p. 49-53.

[11] Bohdanova Yu., 2018, Urban landscapes. Today and tomorrow. Architecture: Lviv Polytechnic National University bulletin. no. 895. p. 11-14.

[12] Wehle-Strzelecka S., 2018, A modern European city-challenges, prospects and the view of the world. Architecture: Lviv Polytechnic National University bulletin. no. 895. p. 89-94.

[13] Kozub V., 2019, Artistic glass in architecture. Architecture: Lviv Polytechnic National University bulletin. V. 1, no. 2 s. p. 23-29.

[14] Harbaum B., 2019 "Controlled cities" as an urban approach towards designing small towns in the future by the example of small towns of Saxony (Germany)". Architecture: Lviv Polytechnic National University bulletin. V.1, no. 2 s. p. 21-26.

[15] Proskuryakov O. V., Yuriychuk R. D., 2019, Architecture of the future: realia and illusions. Architecture: Lviv Polytechnic National University bulletin. V.1, no. 2 s. p. 57-62.

\section{ONLINE SOURCES}

[1] https://en.tangeweb.com/works/works no-22/ (accessed: 10.02.2020)

[2] https://revistabifrontal.com/archigram-la-arquitectura-como-rebelion-nomada/ (accessed: 10.02.2020)

[3] https://www.nytimes.com/2015/08/28/arts/design/review-endlesshouse-expands-the-definition-of-home.html (accessed: 14.03.2020)

[4] https://ukranews.com/ua/news/531857-z-byudzhetu-kyyeva-naskandalnyy-teatr-na-podoli-vydilyly-vtrychi-bilshe-nizh-roshen-zmi(accessed: 14.09.2018)

[5] https://zefir.ua/art/21505-elbphilharmonie-filarmoniya-budushhego.html (accessed: 14.09.2018)

[6] https://archello.com/project/netherlands-institute-for-sound-andvision-hilversum\#stories (accessed: 10.09.2019)

[7] https://yuxiangwei4521.wordpress.com/2010/06/07/retrospectiveinterior-design-the-twist-world-of-castles/ (accessed: 14.03.2020)

[8] https://commons.wikimedia.org/wiki/File:BMW Welt, M\%C3\% BAnich, Alemania16.jpg (accessed: 12.02.2020)

[9] http://modernesia.blogspot.com/2009/11/martin-luther-king-jrmemorial-library.html (accessed: 13.02.2020)

[10] http://lotosbeton.dp.ua (accessed: 13.02.2020) 